\title{
DETERMINATION OF KINETIC PARAMETERS OF AN UPFLOW ANAEROBIC SLUDGE BLANKET REACTOR (UASB), TREATING SWINE WASTEWATER
}

\author{
Determinação dos parâmetros cinéticos de um reator anaeróbio de \\ manta de lodo (UASB), tratando efluente líquido de suinocultura
}

\author{
Mario Tauzene Afonso Matangue ${ }^{1}$, Claudio Milton Montenegro Campos ${ }^{2}$
}

\begin{abstract}
This research aimed to estimate the kinetic parameters of a UASB reactor treating swine wastewater from farming. The system consisted of: a degritter with a triangular-notch weir in order to measure the flow; a static sieve; an acidification/equalization tank (AET); ABR and UASB reactors; a settling tank; two infiltration ponds and a greenhouse for fertirrigation. The hydraulic retention times (HRT) adopted for the UASB reactor, were: 8.0; 9.6; 8.4; 6.0 and 4.8 hours. The operational temperature was $23.4^{\circ} \mathrm{C} \pm 1.5^{\circ} \mathrm{C}$. The analyzed physical-chemical parameters were temperature COD (total and filtered), BOD (total and filtered), total volatile solids (affluent, effluent and of the reactor's profile sludge), flow rate and nutrients ( $\mathrm{N}$ and $\mathrm{P}$ ). The kinetic coefficients estimated were: growth coefficient $\mathrm{Y}=0.091 \mathrm{mg}$ tCOD mg TVS ${ }^{-1} . \mathrm{d}^{-1}$, decay coefficient $\mathrm{K}_{\mathrm{d}}=0.01 \mathrm{~d}^{-1}$; concentration of limiting substrate $\mathrm{K}_{\mathrm{s}}=282.5$ tCOD mg L ${ }^{-1}$ and maximum growth rate $\mu_{\max }=0.051 \mathrm{~d}^{-1}$. For data validation, simple linear regression models were applied and their interaction verified with a " $t$ " test. The results matched with the those found in other references for the same type of kinetic studies.
\end{abstract}

Index terms: Swine wastewater, kinetic, UASB reactor.

\section{RESUMO}

Foram estimados e analisados os parâmetros cinéticos em um reator UASB construído com a finalidade de reduzir a carga orgânica de efluentes líquidos originados de uma granja suinícola. O sistema foi composto de caixa de areia equipada com vertedor Thompson para a medição da vazão, uma peneira estática para a separação de sólidos, tanque de acidificação e equalização (TAE), um RAC e um UASB, tanque de decantação, duas lagoas de infiltração e uma casa de vegetação destinada a fertirrigação. Os tempos de detenção hidráulica (TDH) adotados no reator UASB foram de 8.0; 9.6; 8.4; 6.0 e 4.8 horas. A temperatura média operacional foi de $23,4^{\circ} \mathrm{C} \pm 1,5^{\circ} \mathrm{C}$. Foram analisados os seguintes parâmetros físico-químicos: temperatura, vazão, sólidos totais (SFT e SVT) afluente, efluente, perfil de sólidos, (total e filtrado) DQO, (total e filtrado) DBO e nutrientes (N e P). Os parâmetros cinéticos calculados foram: coeficiente de crescimento $\mathrm{Y}=0,091 \mathrm{mg}$ DQO $\mathrm{mg} \mathrm{SVT}^{-1} \mathrm{~d}^{-1}$, coeficiente de decaimento $\mathrm{K}_{\mathrm{d}}=0,01 \mathrm{~d}^{-1}$, taxa máxima de crescimento

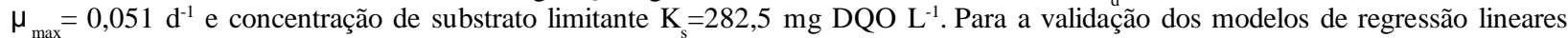
obtidos a partir dos dados coletados foi aplicado o teste "t"e os resultados estão de acordo com os encontrados na bibliografia.

Termos para indexação: Águas residuárias de suínos, cinética, reator UASB.

(Received in july 8, 2011 and approved in september 5, 2011)

\section{INTRODUCTION}

Hog farming is considered to be one of the most troublesome national farming practices due to its rapid growth, increasing production from 26.5 million animals in 1993 to 35.7 million in 2007, placing Brazil as the fourth largest producer and largest regional producer in Latin America. The state of Santa Catarina is the largest domestic producer with approximately 4.5 million livestock (IBGE, 2007); and the state of Minas Gerais has the country's fourth largest herd of about 3.62 million animals (ANUALPEC 2006).

The environmental damage caused by this sector is related to the manure and flushing waste from highdensity confinment facilities. When disposed into waterbodies (either through soil or applied to directly croplands) without a previous treatment they cause serious environmental imbalances as they are defined by high levels of organic matter including nitrogen, phosphorus, potassium, calcium, sodium, magnesium, manganese, iron, zinc, copper and other elements included in the diets of these animals (OLIVERA; DUDA, 2009).

According to Seganfredo (2007), pig slurry can lead to eutrophication of surface waters due to the presence of nitrogen and phosphorus when disposed into water bodies, thereby causing loss of biodiversity by hypoxia, water contamination and waterborne diseases and concomitantly compromising the water standards and quality.

\footnotetext{
1Polytechnic Institute of Gaza/ISPG - Avenue Eduardo Mondlane-Chokwe - Gaza - Mozambique - mathauz@yahoo.com.br ${ }^{2}$ Federal University of Lavras / UFLA - Department Engineering / DEG - Lavras - MG - Brazil
} 
Thus, the Uplfow Anaerobic Sludge Blanket (UASB) reactor represents a breakthrough in anaerobic technology, capable of handling various types of wastewater - such as swine wastewater. In the UASB reactor the stabilization of organic matter occurs in two reaction zones, namely in bed and sludge blanket. The mixing system in the UASB reactor is promoted by the upward flow of the fluid and biogas bubbles, thereby helping the process of contact between biomass and substrate. The UASB reactor has a solid, liquid and biogas separator device fitted at the top, called three-phase separator (TPS), which helps the settling of solids (CHERNICHARO, 2007).

However, an understanding of the kinetic process is vital in the design, development and operation of UASB reactors. Based on the biochemistry and microbiology of anaerobic process, kinetics provide a judicious basis for process analysis, control, and design (BHUINA e GHANGREKAR, 2008).

Moreover, through kinetic modeling, important information can be obtained, namely: Maximum specific rate of growth of biomass $\left(\mu_{\max }\right)$, saturation coefficient $\left(\mathrm{K}_{\mathrm{s}}\right)$, decay coefficient $\left(\mathrm{k}_{\mathrm{d}}\right)$ and the yield coefficient $(\mathrm{Y})$. Amongst the various mathematical models used to describe kinetics, the Monod model is the most applied, based on the principle that the growth rate of microorganisms is proportional to the consumption of substrate (CAMPOS et al. 2005). The major objective of this study is to determine the kinetic behavior of a pilot-scale UASB reactor operated in series and receiving effluent from an Anaerobic Baffled Reactor (ABR), both treating swine wastewater.

\section{MATERIAL ANDMETHODS}

The studies were carried out in a pilot plant designed to treat swine effluent and installed in the Department of Animal Science, at the Federal University of Lavras (UFLA). The wastewater came from hog raising pens, inhabited by 400 animals, and was conducted to the treatment system by gravity, through $200 \mathrm{~mm}$ PVC tubes and then introduced via a static screen where phase separation occurred, the liquid part being channeled to an acidification/equalization tank (AET) and the solids to solid-bed drainage (SBD). From the AET the liquid effluent was conducted to the ABR and then to UASB reactor. After the secondary treatment it was driven by gravity to a settling tank and then utilized for fertigation into a greenhouse. The UASB reactor had a working volume of 3823.62 liters, and was built in brick masonry waterproofed with an asphalt blanket and then covered with fiberglass. At the top of the reactor a three-phase-separator (TPS) was installed, through which the biogas produced was retained and then conducted to a hydrostatic tank and afterwards burnt up in an appropriate device.

The start-up of the reactor was in June 2010, without inocullum up to January 2011 and the local temperature ranged from $21.9-24.9^{\circ} \mathrm{C}$. The physical-chemical properties analyzed were: temperature, $\mathrm{pH}$ and flowrate were measured daily; alkalinity, total acidity, settleable, COD (total and filtered), BOD (total and filtered) and electrical conductivity were measured three times per week; total solids (fixed, volatile and dissolved), twice per week and lastly phosphorus, TKN and oils \& greases were measured once per week. All measurements of physical-chemical properties were performed according to methodology described by Apha (1998). Only total COD (tCOD) and volatile solids (VS) from influent and effluent, sludge bed volume and inflow rate data were used to determine kinetic constants or parameters according to the models deduced in this article.

The reactor was submitted to five different HRT, namely $8.0 ; 9.6 ; 8.4 ; 6.0$ and 4.8 hours, aiming to screen the most efficient one in terms of COD removal. The first one comprised start-up period and lasted approximately 100 days and the others had the maximum duration of 21 days for each, considered to be the period of time enough for the reactor to operate in steady-state. The total Volatile solids (TVS) were performed through sludge profile along the reactor height, summing up 47 samples in whole experiment. The $\mathrm{COD}$ reflux reaction was performed, using a COD digester (Hach , 45600-00) fitted with a timer and alarm to allow complete oxidation and thereof, analyzed at a $600 \mathrm{~nm}$ wavelength using a visible spectrophotometer (Químis 798). All kinetic coefficients were determined under steady-state conditions using a set of 47 consistent observations, without discriminating each HRT.

\section{Modelling for maximum specific growth rate $\left(\mu_{\max }\right)$ and saturation concentration $(\mathrm{Ks})$}

The kinetic parameters were determined using the Monod kinetic model, described by Campos et al. (2005) and Bhunia; Ghangrekar (2008), briefly deduced herein as follow:

Inflow - outflow $=$ Acumulation - Conversation

$$
\frac{\mathrm{d}(\mathrm{CV})}{\mathrm{dt}}=\left(\mathrm{QC}_{\mathrm{o}}-\mathrm{QC}\right)+\left(\mu \cdot \mathrm{X}_{\mathrm{r}} \mathrm{V}_{\mathrm{r}}-\mathrm{K}_{\mathrm{d}} \cdot \mathrm{X}_{\mathrm{r}} \mathrm{V}_{\mathrm{r}}\right)
$$

Where: $X_{r}=$ concentration of biomass in the effluent (mg $\left.\mathrm{L}^{-1}\right)$; X: concentration of biomass of the effluent $\left(\mathrm{mg} \mathrm{L}^{-1}\right)$; $\mathrm{Co}=$ : the afluent substrate concentration $\left(\mathrm{mg} \mathrm{L}^{-1}\right) ; \mathrm{C}=$ the substrate concentration in the effluent $\left(\mathrm{mg} \mathrm{L}^{-1}\right), \mu$ : specific 
growth rate $\left(\mathrm{d}^{-1}\right)$ and $\mathrm{Q}=$ Flowrate $\left(\mathrm{d}^{-1}\right)$ and $\mathrm{Vr}=$ reactor volume.

Decoupling the first term of Equation 1 and assuming that the volume is fixed in this biological reactor the Equation 2 is obtained:

$\mathrm{V} \frac{\mathrm{dC}}{\mathrm{dt}}=\left(\mathrm{QC}_{\mathrm{o}}-\mathrm{QC}\right)+\left(\mu \cdot \mathrm{X}_{\mathrm{r}} \mathrm{V}_{\mathrm{r}}-\mathrm{K}_{\mathrm{d}} \cdot \mathrm{X}_{\mathrm{r}} \mathrm{V}_{\mathrm{r}}\right)$

In "steady-state" condition, the change in concentration in the reactor is zero, therefore:

$0=\left(\mathrm{QC}_{\mathrm{o}}-\mathrm{QC}\right)+\left(\mu \cdot \mathrm{X}_{\mathrm{r}} \mathrm{V}_{\mathrm{r}}-\mathrm{K}_{\mathrm{d}} \cdot \mathrm{X}_{\mathrm{r}} \mathrm{V}_{\mathrm{r}}\right)$ obtained.

Rearranging equation 3 the following equation is

$$
\frac{\mathrm{Q} \cdot \mathrm{C}_{\mathrm{o}}+\mathrm{Q} \cdot \mathrm{C}}{\mathrm{V}_{\mathrm{r}} \cdot \mathrm{X}_{\mathrm{r}}}=\mu-\mathrm{K}_{\mathrm{d}}
$$

According to Metcalf e Eddy (2003), the cell retention time $\left(\theta_{c}\right)$ is given by:

$$
\theta_{\mathrm{c}}=\frac{\mathrm{V}_{\mathrm{r}} \cdot \mathrm{X}_{\mathrm{r}}}{\mathrm{Q} \cdot \mathrm{C}_{\mathrm{o}}+\mathrm{Q} \cdot \mathrm{C}}
$$

Coupling equations 4 with 5 and rearranging terms, equation 6 is generated as follows:

$\frac{1}{\theta_{\mathrm{C}}}=\mu-\mathrm{K}_{\mathrm{d}} \Rightarrow \mu=\frac{1}{\theta_{\mathrm{c}}}+\mathrm{K}_{\mathrm{d}}$

However, it is well known that " $\mu$ " is expressed through Monod's kinetic as shown below.

$$
\mu=\mu_{\max } \frac{S}{K s+S}
$$

Therefore rearranging Equation 6 and Equation 7:

$$
\mu_{\max } \frac{\mathrm{S}}{\mathrm{Ks}+\mathrm{S}}=\frac{1}{\theta_{\mathrm{c}}}+\mathrm{K}_{\mathrm{d}}
$$

From rearranging and linearizing equation 8 , equation 9 is obtained:

$$
\frac{1}{\left(\frac{1}{\theta_{c}}+K_{d}\right)}=\frac{K s}{\mu_{\max } \cdot S}+\frac{1}{\mu_{\max }}
$$

Thus, equation 9 may be written as simple linear regression model (SLRM):

$\left(\mathrm{y}=\beta_{0}+\beta_{1} \mathrm{x}_{\mathrm{i}}+\mathrm{e}_{\mathrm{i}}\right)$

Where: $\beta_{0}$ and $\beta_{1}$ is intercept and slope coefficient of the linear regression model (SLRM).

Equation 10, represents the SLRM that was used to estimate the kinetic coefficients $\mu_{\max }$ and $\mathrm{K}_{\mathrm{s}}$ using the method of least squares and the relationship between kinetic coefficients and the estimators can be seen in equations 11,12 and 13.

$\mathrm{y}=\frac{1}{\frac{1}{\theta_{c}}+\mathrm{K}_{\mathrm{d}}} ; \hat{\beta_{0}}=\frac{1}{\mu_{\max }} ; \hat{\beta_{1}}=\frac{\mathrm{K}_{\mathrm{s}}}{\mu_{\max }}$

Modelling for endogenous decaying $\left(K_{d}\right)$ and yield coefficient $(Y)$ parameters

$\mathrm{V} \frac{\mathrm{dC}}{\mathrm{dt}}=\left(\mathrm{QC}_{\mathrm{o}}-\mathrm{QC}\right)+\mathrm{X}_{\mathrm{r}} \mathrm{V}_{\mathrm{r}} \cdot\left(\mu-\mathrm{K}_{\mathrm{d}}\right)$

The gross growth of the bacterial population is given by the following formula:

$\frac{\mathrm{dX}}{\mathrm{dt}}=\mu \mathrm{X}$

And substituting equation 15 for the last term of 14 gives equation 16 :

$\mathrm{V} \frac{\mathrm{dC}}{\mathrm{dt}}=\left(\mathrm{QC}_{\mathrm{o}}-\mathrm{QC}\right)+\mathrm{V}_{\mathrm{r}} \cdot \frac{\mathrm{dX}}{\mathrm{dt}}$

Considering the reactor in steady-state condition:

$0=\left(\mathrm{QC}_{\mathrm{o}}-\mathrm{QC}\right)+\mathrm{X}_{\mathrm{r}} \mathrm{V}_{\mathrm{r}} \cdot \frac{\mathrm{dX}}{\mathrm{dt}}$

Equation 17 can be expressed as follows:

$\frac{-\left(\mathrm{QC}_{\mathrm{o}}-\mathrm{QC}\right)}{\mathrm{X}_{\mathrm{r}} \mathrm{V}_{\mathrm{r}}}=-\frac{1}{\mathrm{Y}} \cdot \mu$

Equation 18 can be expressed as follows:

$\frac{\left(\mathrm{QC}_{\mathrm{o}}-\mathrm{QC}\right)}{\mathrm{X}_{\mathrm{r}} \mathrm{V}_{\mathrm{r}}}=\frac{1}{\mathrm{Y}} \cdot \frac{1}{\theta_{\mathrm{C}}}+\frac{\mathrm{K}_{\mathrm{d}}}{\mathrm{Y}}$

Therefore Equation 19 can be represented as follows:

$\left(\mathrm{y}=\beta_{0}+\beta_{1} \mathrm{x}_{\mathrm{i}}+\mathrm{e}_{\mathrm{i}}\right)$ 
Likewise, this equation represents the model that will be used for determining the kinetic coefficients $\mathrm{Y}$ and $\mathrm{K}_{\mathrm{d}}$ as shown in the equations, 21, 22 and 23.

$\hat{\mathrm{y}}=\frac{\mathrm{Q} \cdot\left(\mathrm{S}_{0}-\mathrm{S}\right)}{\mathrm{V}_{\mathrm{r}} \cdot \mathrm{X}}, \hat{\beta}_{0}=\frac{\mathrm{K}_{\mathrm{d}}}{\mathrm{Y}}, \hat{\beta}_{1}=\frac{1}{\mathrm{Y}}$

\section{Model description and validation}

To verify whether the SLRM conforms to the collected data or not, a " $t$ " test was used, according to the methodology proposed by Ferreira (2009), at a significance level of $5 \%$. The tests were done based on two statistical hypotheses, the first stateing that intercept $\left(\hat{\beta}_{0}\right)$ and slope $\left(\hat{\beta}_{1}\right)$ are equal to zero, the latter one stating the contrary as shown in expression 24. The graphs were generated through MS Excel ${ }^{\circledR}$.

$$
\mathrm{H}_{\mathrm{o}}: \widehat{\beta}_{0} \text { vs } \mathrm{H}_{\mathrm{a}}: \widehat{\beta}_{1} \neq 0 \quad \mathrm{H}_{\mathrm{o}}: \widehat{\beta}_{0}=0 \text { vs } \mathrm{H}_{\mathrm{a}}: \widehat{\beta}_{0} \neq 0
$$

According to Ferreira (2009) the "t" test for the estimator $\hat{\beta}_{0}$ is given by equation 25 :

$$
\mathrm{t}_{\text {cal }}=\frac{\hat{\beta}_{0}-\beta_{0}}{\mathrm{~S} \sqrt{\sum_{\mathrm{i}=1}^{\mathrm{n}} \mathrm{x}_{\mathrm{i}}^{2} /(\mathrm{nSQX})}}
$$

The amount has Pivot Student " $t$ " distribution with $v=\mathrm{n}-2$ degrees of freedom.

Similarly, for the parameter of this model $\beta_{1}$, one can show that the amount pivot (equation 26):

$$
\mathrm{t}_{\mathrm{cal}}=\frac{\hat{\beta_{1}}-\beta_{1}}{\mathrm{~S} / \sqrt{\mathrm{SQX}}}
$$
freedom.

Student " $\mathrm{t}$ " distribution has to $v=\mathrm{n}-2$ degrees of

Where: $t_{\text {cal }}=$ Calculated" $t$ " test; $\beta_{0}$ and $\beta_{1}=$ Intercept and Slope of the linear regression model (LRM), $\hat{\beta}_{0}$ and $\hat{\beta}_{1}=$ Estimator of $\beta_{0}$ and $\beta_{1}$ of LRM ;S = Standard deviation; $\sum_{i=1}^{n} x_{i}^{2}=$ Sum of the squares of the variable $x ; n=$ number of observation, $\mathrm{SQX}=$ Sum of squares of $\mathrm{X}$

\section{Determination of the confidence interval, Correlation coefficient adjusted and Error analysis}

Thus, according to Ferreira (2009), the confidence interval for $\beta_{1}$ and $\beta_{0}$ can be given by the equation 27 :
$\mathrm{CI}_{1-\beta_{0}}\left(\beta_{\mathrm{o}}\right): \hat{\beta}_{0} \pm \mathrm{t}_{\alpha / 2, \mathrm{v}} \times \mathrm{S} \sqrt{\left[\sum_{\mathrm{i}=1}^{\mathrm{n}} \mathrm{x}_{\mathrm{i}}^{2} /(\mathrm{nSQX})\right]}$

Similarly $\beta_{1}$ for in the range of $100(1-\alpha) \%$ confidence, as shown through equation 28 :

$\mathrm{IC}_{1-\alpha}\left(\beta_{1}\right): \hat{\beta}_{1} \pm \mathrm{t}_{\alpha / 2, \mathrm{v}} \times \mathrm{S} / \sqrt{\mathrm{SQX}}$

Where: $\mathrm{CI}=$ Confidence interval $\mathrm{t}_{\alpha / 2, \mathrm{v}}$ and $=$ " $\mathrm{t}$ " test tabulated in upper quantiles $\alpha / 2$ and $v$ the degree of freedom (n-1)

The adjusted correlation coefficient is given by the equation 29:

$\mathrm{R}_{\text {aju }}{ }^{2}=1-[(\mathrm{n}-\mathrm{I}) /(\mathrm{n}-\mathrm{k})]\left(1-\mathrm{R}^{2}\right)$

Where:

$\mathrm{R}^{2}=$ Correlation coefficient; $\mathrm{R}_{\text {aju }}^{2}=$ Correlation coefficient adjusted, $\mathrm{k}=$ Number of parameters in the model and $\mathrm{I}=$ variable indicator that equals to 1 if the model has intercept and set equal to 0 otherwise.

For error analyis, the most commonly used error function in SLRM was adopted, according to which, the sum of the differences between observed and estimated values must be zero (equation 30).

$\sum_{i=1}^{n} \hat{e}_{i}=\sum_{i=1}^{n}\left(y_{i}-\hat{y}\right)=0$

Where: $e_{i}:$ is the error, yi: observed value and $\hat{y}:$ is the estimated value

\section{RESULTS AND DISCUSSION}

According to Figure 1, the SLRM was obtained and represented by equation 31 below

$y=19.55+5519.9 x$

Where: $\hat{\beta}_{0}=19.55$ and $\hat{\beta}_{1}=5519.9011$

Using the equation 12 and 13, the values of the coefficients $\mu_{\max }$ and $\mathrm{K}_{\mathrm{s}}$ are $0.051 \mathrm{~d}^{-1}$ and $282.45 \mathrm{mg} \mathrm{L}^{-1}$, respectively. The correlation coefficient was $\mathrm{r}^{2}=0.75$, showing that the SLRM explains $86 \%$ the variation of the maximum specific growth rate $\left(\mu_{\max }\right)$ and saturation coefficient $\left(\mathrm{K}_{\mathrm{s}}\right)$. 


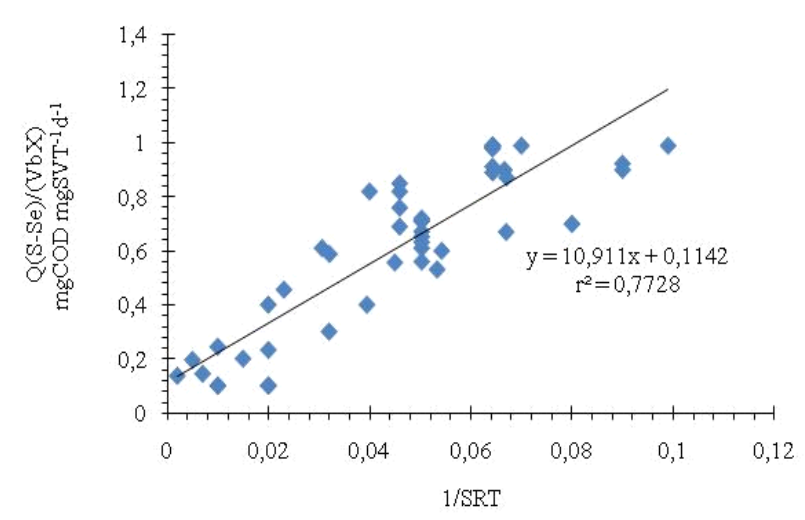

Figure1 - Linear regression to determine the coefficients $\mathrm{Y}$ and $\mathrm{K}_{\mathrm{d}}$ of the UASB reactor.

Smilary for the determination of $\mathrm{Y}$ and $\mathrm{K}_{\mathrm{d}}$ coefficients, the LRM presented in the Figure 2 was used and thereby the Equation 32 obtained.

$y=0.11+10.91 x$

Where: $\hat{\beta}_{0}=0.11$ and $\hat{\beta}_{1}=10.911$

Using the equations 22 and 23 and from estimators values of and the corresponding kinetics coefficients $\mathrm{K}_{d}$ and $\mathrm{Y}$ were determined, which values were: $\mathrm{Y}=0.091 \mathrm{mg} \mathrm{tCOD} \mathrm{mg} \mathrm{TVS}{ }^{-1} \cdot \mathrm{d}^{-1}$ and $\mathrm{K}_{\mathrm{d}}=0.0104 \mathrm{~d}^{-1}$ and the correlation coefficient was $r^{2}=0.77$, showing that about $88 \%$ of the yield coefficient (Y) and decay coefficient $\left(\mathrm{k}_{\mathrm{d}}\right)$ are explained by the cell retention time.The estimators and the respective kinetics parameters are clearly shown in the Table 1 while the determination coeficients and the errors analysis are shown in the Table 2.

On the other hand the correlation $f$ adjusted coefficients and in the Table 2 , show that their values are close to the coefficients obtained directly from the models, thus implying a good fit related to the data collected. With respect the error analyzed, also shown in

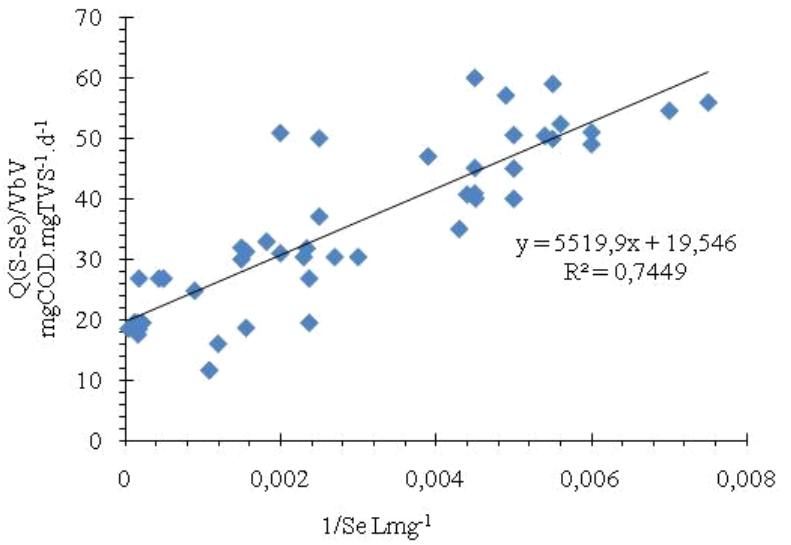

Figure 2-Linear regression to determine the coefficients $\mu_{\max }$ and $\mathrm{K}_{\mathrm{s}}$ of UASB reactor.

the Table 2 , it is clear that, for both models, the sum of errors was greater than zero, implying that, although the data fit the statistical models, there is still a residual error in these models, even though it is quite small: According to Ferreira (2009), when the error value is closer to zero, the greater is degree of adjustment of the model, consequently the phenomenon under study is considered accurately described.

\section{Validation of the models and the kinetic parameters}

The confidence interval for maximum growth rate $\left(\mu_{\max }\right)$, was determined using Equation 27, calculated from the initial estimator $\hat{\beta}_{0}$ from SLRM reperesented in the Equation 31. Thus the "t" teste value was 11,45 and the tabulated 1,64, calculted at nominal 5\% significance level and 46 degrees of freedom. The calculated one was greater than the tabulated, hence it is possible to reject the null hypothesis, meaning that $\hat{\beta}_{0}$ is different from zero, thereby $\mu_{\max }$, is statistically different from zero and fits to the experimental data as well, as shown in the Table 2 and 3 , where the interval and the calculated " $\mathrm{t}$ " values for all others kinetics parameters are presented. Similary the

Table 1 - The models, the estimators and kinetics parameters UASB reactor.

\begin{tabular}{lll}
\hline Model & \multicolumn{1}{c}{ Estimators values } & Values of kinetics parameters \\
\hline \multirow{3}{*}{$\mathrm{y}=19.55+5519.9 \mathrm{x}$} & $\hat{\beta}_{0}=19.55$ & $\mu_{\max }=0.051 \mathrm{~d}^{-1}$ \\
& $\hat{\beta}_{1}=5519.9$ & $\mathrm{~K}_{\mathrm{s}}=282.45 \mathrm{mg} \mathrm{L}^{-1}$ \\
$\mathrm{y}=0.11+10.91 \mathrm{x}$ & $\hat{\beta}_{0}=0.11$ & $\mathrm{~K}_{\mathrm{d}}=0.0104 \mathrm{~d}^{-1}$ \\
& $\hat{\beta}_{1}=10.91$ & $\mathrm{Y}=0.091 \mathrm{mgSVT}(\mathrm{mgDQO})^{-1} \mathrm{~d}^{-1}$ \\
\hline kinetics order in the reactor & & Zero order \\
\hline
\end{tabular}

Ciênc. agrotec., Lavras, v. 35, n. 6, p. 1204-1210, nov./dez., 2011 
confidence interval of Ks was calculated using Equation 28 and the "t "value was significative showing is statistically different from zero and fits to the experimental data. The $\mathrm{K}_{\mathrm{d}}$ and $\mathrm{Y}$ confidence interval were calculated using equations 27 and 28 respectively. The calculated $t$ values for $\hat{\beta}_{0}$ and $\hat{\beta}_{1}$ were also greater than the tabulated, meaning that the test was sthese estimators are diferente from zero. Therefore $\mathrm{K}_{\mathrm{d}}$ and $\mathrm{Y}$ are also different from zero and fit to the experimental data.The magnitude of fitness of each model presented herein is assessed by correlation coefficient $\left(\mathrm{r}^{2}\right)$ showed in Table 2 and discussed at the beginning of this section.

The values of each estimated kinetic parameter and the confidence inteval as well is shown in the table 2 and 3 . The estimated value of $\mu_{\max }$ was $0.051 \mathrm{~d}^{-1}$ and the respective statistical range $0.045 \leq \mu_{\max } \leq 0.056 \mathrm{~d}^{-1}$ and the $\mu_{\max }$ so is within a fairly acceptable range as shown by table. Studies conducted by Henze et al. (1997), in anaerobic reactors, had similar values in the range of 0.03 to $0.075 \mathrm{~d}^{-1}$. According to Von Sperling (2006), in anaerobic processes, $\mu_{\max }$ values can reach up to $0.4 \mathrm{~d}^{-1}$. Research by Masse; Massé (2010), in Canada, using fed batch reactors treating swine effluent, obtained even lower values, around $0.005 \mathrm{~d}^{-1}$. These values were related to the low operating temperature, but when the reactors were subjected to mesophilic conditions, the maximum specific growth rate increased to $0.12 \mathrm{~d}^{-1}$.

The value of $\mathrm{K}_{\mathrm{s}}$ is $282.45 \mathrm{mg} \mathrm{L}^{-1}$ and may vary statistically from 252.43 to 311.53 and was apparently very high, since the average value found in the literature is about $500 \mathrm{mg} \mathrm{L}^{-1}$ (MASSE; MASSÉ 2010; PAN; DAPCHO 2001). The high value was due to the high biological organic loading rate (BOLR), caused by lowering the HRT. The rate of substrate removal using the Monod equation, given the value of $\mathrm{K}_{\mathrm{s}}=282.45 \mathrm{mg} \mathrm{L}^{-1}$, which is much smaller when compared to the average concentration of the substrate $\left(\mathrm{tCOD}=1473 \mathrm{mgL}^{-1}\right.$ ), allows to affirm that $\mathrm{K}_{\mathrm{s}}<<$ Se, hence $\mu=\mu_{\max }$. Therefore it can be concluded that the overall kinetic process which ruled the removal of tCOD in the UASB reactor, was zero order..

Reagrad to the Y values, Metcalf; Eddy (2003), stated that in the anaerobic processes $Y$ varies from 0.03 to $0.15 \mathrm{mg} \mathrm{tCOD} \mathrm{mg} \mathrm{TVS}{ }^{-1}$. $\mathrm{d}^{-1}$ and the value determined in this work was $0.091 \mathrm{mg}$ tCOD $\mathrm{mg} \mathrm{TVS}^{-1}$. $\mathrm{d}^{-1}$, ranging from $0.081 \leq \mathrm{Y} \leq 0.105 \mathrm{mg}$ tCOD mg TVS ${ }^{-1} . \mathrm{d}^{-1}$. Studies conducted in UASB reactor by Fox; Lim (2010), treating swine wastewater in temperate climates allowed to obtain $\mathrm{Y}$ values of $0.45 \mathrm{mg} \mathrm{COD} \mathrm{mg} \mathrm{TVS}^{-1}$. $\mathrm{d}^{-1}$. Campos et al., (2005), working in kinetic parameters for the same type of effluent on a

Table 2 - Correlation and the adjusted coefficients for both models and their errors.

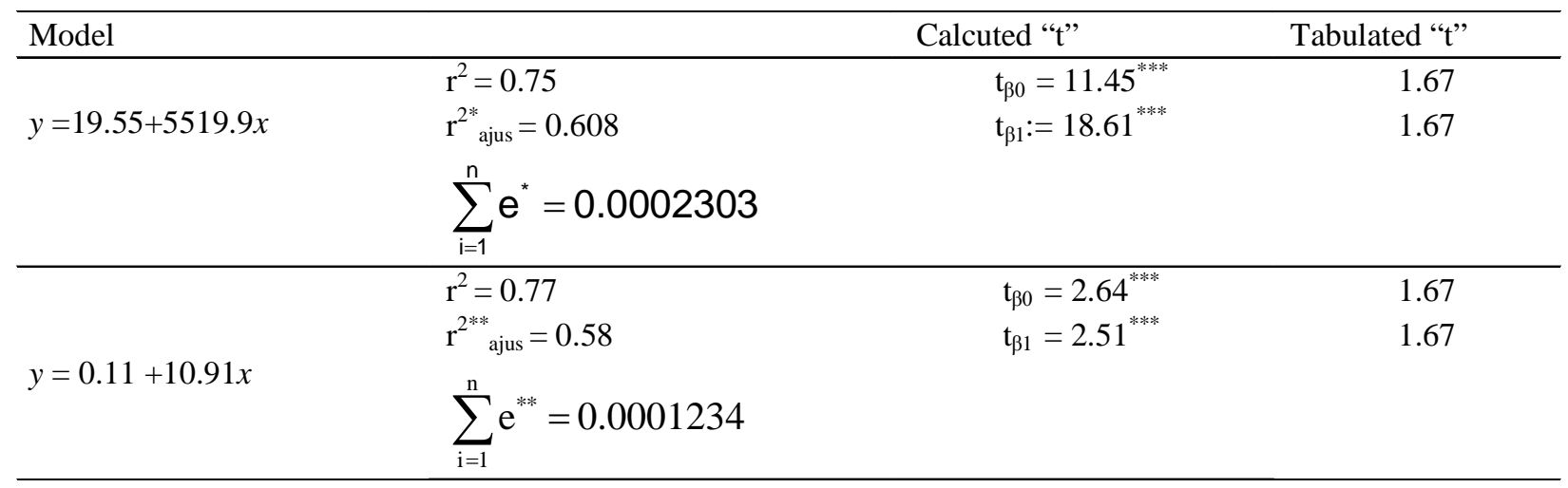

Table 3 - The estimators and kinetic parameters confidence interval for both SLRM.

\begin{tabular}{ccc}
\hline Models & Estimator C.I & Kinetics parameter C I \\
\hline & $19.27 \leq \leq 19.87$ & $0.045 \leq \mu_{\max } \leq 0.056 \mathrm{~d}^{-1}$ \\
\cline { 2 - 3 } $\mathrm{y}=19.55+5519.9 \mathrm{x}$ & $252.43 \leq \leq 311.53$ & $252.43 \leq \mathrm{K}_{\mathrm{s}} \leq 311.53 \mathrm{mg} \mathrm{L}^{-1}$ \\
\cline { 2 - 3 } $\mathrm{y}=0.11+10.91 \mathrm{x}$ & $0.1 \leq \leq 0.13$ & $0.0012 \leq \mathrm{K}_{\mathrm{d}} \leq 0.014$ \\
\cline { 2 - 3 } & $9.46 \leq \leq 12,36$ & $0.081 \leq \mathrm{Y} \leq 0.105$ \\
\hline
\end{tabular}


laboratory scale, found $\mathrm{Y}$ values ranging from 0.045 to $0.4231 \mathrm{mg}$ COD mg TVS ${ }^{-1}$. $\mathrm{d}^{-1}$. Of course, this interval suggest greater values of $\mathrm{Y}$ than those found in present work, probably because the experiment was carried out under low temperatures (winter) observed during the experiment and high volumetric organic loading rates.

As for $\mathrm{K}_{\mathrm{d}}$, Metcalf and Eddy (2003), stated that in anaerobic processes this constant is highly variable, depending on the reactor's effluent. Studies by Pan; Dapcho (2001), in facultative ponds, showed a variation of $\mathrm{K}_{\mathrm{d}}$ in the range from 0.02 to $0.040 \mathrm{~d}^{-1}$. Many authors have found values in the same range, however some studies have shown even lower values, as that found by Campos (2005), in an experiment that determined a $\mathrm{K}_{\mathrm{d}}$ of $0.0138 \mathrm{~d}^{-1}$, value close to that determined in the UASB reactor in this study.

\section{CONCLUSION}

In this present research, the determined models are properly adjusted and consequently consistent.The kinetic parameters estimated in the UASB reactor were: Specific maximum growth rate $\mu_{\max }=0.052 \mathrm{~d}^{-1}$, limiting substrate concentration $\mathrm{K}_{\mathrm{s}}=282.6 \mathrm{mg} \mathrm{L}^{-1}$, decay coefficient $\mathrm{K}_{\mathrm{d}}=0.01 \mathrm{~d}^{-1}$ and yield coefficient $\mathrm{Y}=0.0910 \mathrm{mg} \mathrm{tCOD} \mathrm{mg} \mathrm{TVS}{ }^{-1} . \mathrm{d}^{-1}$ and the removal of organic matter was governed by zero order kinetic, since the values of saturation coefficient $\left(\mathrm{K}_{\mathrm{s}}\right)$ was much lower than the concentration of substrate that entered in the reactor.

\section{ACKNOWLEDGEMENTS}

The authors thank the Polytechnic of Gaza (ISPG) Mozambique/Chokwe, the NUFFIC (Netherlands Organization for International Cooperation and Higher Education) for the sponsorship and also UFLA, FAPEMIG, CAPES and CNPq for their support .

\section{REFERENCES}

ANUALPEC. Anuário da Pecuária Brasileira. Instituto FNP, São Paulo.2006, 369 p.

BHUNIA, P.; GHANGREKAR, M. M. Analysis, evaluation, and optimization of kinetic parameters for performance appraisal and design of UASB reactors. Bioresource Technology. London, v.99, n. 78, p. 2132-2140, May 2007

CAMPOS,C. M. M; SALÉH. B.B; CARMO.F R.

Determination of kinetic parameters of a lab-scale upflow Anaerobic sludge blanket reator (UASB) removing organic Loading from swine manure effluents. Revista Agrociência.v. 29, n. 5, p. 1045-1051, 2005
CHERNICHARO, C. A. L. Reatores anaeróbios:

Princípios do tratamento biológico de águas residuárias. Belo Horizonte: Politécnica, 2007. 379 p.

FERREIRA. F. D. Estatística Básica. $2{ }^{\text {a }}$ Edição Revisada. Editora UFLA. 663. P 2009.

FOX, P. E.; LIM, J. S. A kinetic evaluation of anaerobic treatment of swine wastewater at two temperatures in a temperate climate zone. Bioresource Technology.

London, v.87, n. 42, p 8878-8886, July 2010.

HENZE, M. Trends in advanced wastewater treatment. Water Science Technology. Oxford, v. 35, n 34, p. 1-4, May 1997

\section{INSTITUTOBRASILEIRODE GEOGRAFIA E ESTATÍSTICA(IBGE). Pesquisa pecuária municipal. 2007. Rio de Janeiro. v 34. 39 p}

MASSE, L.; MASSÉ, L. D. The effect of environmental and process parameters on flocculation treatment of high dry matter swine manure with polymers.

Bioresource Technology. Oxford v. 101, n.56, p. 63046308, April 2010.

METCALF; EDDY INC. Wastewater engeneering treatment, disposal and reuse. 4. ed. New York: McGraw Hill, 2003. 822 p.

PAN, T. P.; DRAPCHO, M. C. Biological anoxic/aerobic treatment of swine waste for reduction of organic carbon, nitrogen, and odor: Structures \& Environment Division of ASAE. St. Joseph. v. 41, n. 12 , p1798-1769P. July 2001

SEGANFREDO, M. A. A gestação Ambiental na Suinocultura: Embrapa Suínos e Aves. Brasília, DF. 2007.302 p.

OLIVEIRA, R; DUDA, M. R. Reatores anaeróbios operados em batelada sequencial, seguidos de lagoas de polimento, para o tratamento de águas residuárias de suinocultura: parte 1: produção de metano e remoção de DQO e de sólidos suspensos. Engenharia Agrícola, Jaboticabal, v. 29, n. 1, p. 122-134, jan./mar. 2009.

VON SPERLING. Introdução a qualidade das águas e ao tratamento de esgoto. Volume1. DESA. UFMG. 2006. 211p 